\title{
Black poplar: A model for gene resource conservation in forest ecosystems ${ }^{1}$
}

\author{
by François Lefèvre ${ }^{2}$, Davorin Kajba ${ }^{3}$, Berthold Heinze ${ }^{4}$, Peter Rotach ${ }^{5}$, Sven M.G. de Vries ${ }^{6}$ \\ and Jozef Turok ${ }^{7}$
}

\begin{abstract}
Conservation of genetic resources of forest trees has become a major objective for the management of forests. Much theoretical work has been devoted to the subject, and implementation has already started at the local, national, or international scales. Poplars are probably the most representative and threatened forest tree species of old natural floodplain forests in the temperate zone. Gene conservation needs to be integrated with intensive breeding activities, habitat conservation and restoration. For Populus nigra, while research in genetics and ecology is reinforced, a combined conservation strategy is applied at the European scale; simultaneously, the conservation of riparian ecosystems is also a priority. Research and application benefit from each other. The question now is the evaluation of such an integrated strategy. Criteria and indicators for the follow-up of gene resource management are progressively developed, but still need to be tested on the operational scale.
\end{abstract}

Key words: Populus nigra, poplar, gene resources, in situ conservation, ex situ conservation, riparian ecosystem, sustainable management

La conservation des ressources génétiques s'intègre dans la gestion durable des forêts. De nombreux travaux théoriques ont permis de conceptualiser la conservation des ressources génétiques forestières, la mise en œuvre de tels programmes a débuté à l'échelle locale, nationale, voire internationale. La conservation des ressources génétiques occupe une place centrale entre l'amélioration génétique et la préservation ou la restauration des habitats. Pour le peuplier noir Populus nigra, espèce emblématique des ripisylves des zones tempérées dont les ressources génétiques sont menacées, un programme de conservation intégré est mis en œuvre à l'échelle européenne, appuyé par des projets de recherche en génétique et en écologie. Parallèlement, la préservation des habitats de la ripisylve est aussi une priorité. Les échanges entre recherche et développement, menés en parallèle, sont ici favorisés. La question de l'évaluation d'un tel dispositif est maintenant posée. Des critères et indicateurs ont été proposés pour le suivi de l'efficacité des programmes de conservation, ceux-ci doivent être testés à l' échelle opérationnelle.

Mots-clés: Populus nigra, peuplier, ressources génétiques, conservation in situ, conservation ex situ, ripisylve, gestion durable ESeptember 24-28, 2000, Vancouver, Washington, USA.

${ }^{2}$ INRA, Unité de Recherches Forestières Méditerranéennes, Av. A. Vivaldi, 84000 Avignon, France. E-mail: lefevre@avignon.inra.fr (Author to whom correspondence should be addressed.)

${ }^{3}$ Faculty of Forestry, Svetosimunska 25, 10000 Zagreb, Croatia. E-mail: davorin.kajba@zg.tel.hr

${ }^{4}$ Institut für Forstgenetik, Federal Forest Research Centre FBVA, Hauptstrasse

7, 1140 Vienna, Austria. E-mail: berthold.heinze@fbva.bmlf.gv.at

${ }^{5}$ Swiss Federal Institute of Technology, Department of Forest Science,

ETH-Zentrum, Rämistrasse 101, 8092 Zurich, Switzerland. E-mail: rotach@fowi.ethz.ch

${ }^{6}$ ALTERRA Green World Research, PO Box 47, 6700 AA Wageningen, The Netherlands. E-mail: s.m.g.devries@alterra.wag-ur.nl

${ }^{7}$ IPGRI, Regional Office for Europe, Via delle Sette Chiese 142, 00145 Rome, Italy.E-mail: j.turok@cgiar.org

${ }^{8} \mathrm{See}$ also the web pages www.mmm.fi/english/forestry/policy/minkonf/document_main.htm and www.minconf-forests.net/Basic/FS-MCPFE-Resolution.html

ity concept, gene resource management takes into account both the exploitation and the long-term preservation of a changing resource in a changing environment.

Theoretical concepts in conservation biology were used to establish the first conservation projects in forestry (see, for example, Varela and Eriksson 1995, Namkoong 1997). The current situation is particularly interesting since theory and practical implementation are simultaneously developed. Obviously, theory should guide practical implementation; but in this paper we emphasize the question of the feedback from practical experience into theory and research. The recent implementation of the theory on broad national or international scales gives us an opportunity to: (i) test the accuracy of theoretical predictions, (ii) raise new questions for research. The time has come to look for a first evaluation of the conservation strategies that have been initiated. In that respect, some programs can serve as model situations: poplar conservation projects, and especially that for Populus nigra in Europe, are among them.

The EUFORGEN Network $P$. nigra was initiated by poplar geneticists and forest managers after the FAO/IPC recommendation at the International Poplar Commission Session in Zaragoza in 1992. The scope of the EUFORGEN Network has evolved progressively and, today, a real collaborative effort for the definition of global strategy involves complementary expertise from geneticists to ecologists, from breeders to river managers. In the poplar context, gene resource management has a central position that we explain in this paper. Then, we briefly refer to the combined conservation strategies that are currently developed, emphasizing the interaction between 
research and implementation. Finally, we investigate the possibility of using black poplar as a model for gene resource conservation in forest trees: this would require further developments of concepts and experimentation.

\section{The central role of gene conservation in black poplar}

Poplar cultivation systems in many parts of Europe are becoming increasingly intensive with an increasing demand for new selected material. $P$. nigra is used in the breeding programs for its adaptability to a broad range of ecological conditions, its rooting ability and disease resistance (e.g., to Xanthomonas populi and poplar mosaic virus). In the meanwhile, the reduction of riparian habitats, where native poplar resources come from, is becoming a major concern and specific conservation programs, or even restoration projects ${ }^{9}$, have been launched (European Community 1992). A two-fold objective can then be assigned to poplar gene resource conservation: (i) to preserve a resource needed for further improvement of robust and well-adapted varieties, (ii) to contribute to the maintenance or restoration of priority habitats.

The wild and the cultivated gene pools are often in tight contact, they interact and exchange genes or parasites quite freely. In Europe, the risk of introgression from exotic species (mainly $P$. deltoides and $P$. trichocarpa) was initially thought to be a major problem due to the extensive use of hybrid clones in poplar forestry. Gene flow among the autochthonous and the allochthonous genomes is possible; however, the first genetic studies of this phenomenon suggest that it is rather limited although the mechanisms involved in the restriction of introgression remain unknown (Heinze 1997, Benetka et al. 1999). Nevertheless, final conclusions cannot be drawn today, and the question is still worth investigating for three main reasons: (i) the effective impact of introgression needs to be further evaluated, (ii) the balance between the cultivated and the wild gene pools (very few selected clones propagated on a very wide scale, including $P$. nigra varieties such as the male "italica," versus declining wild poplar stands) will be more and more affected; and (iii) the question of the spread of genetically modified organisms (GMOs) will probably arise very soon in this genus.

Concerning parasites, an extraordinary evolution of the pathogen populations has been observed on the cultivated gene pool in relation to the genetic basis of cultivated material. In cultivated poplar stands, Melampsora rusts are evolving towards an increased diversity of races, measured on the basis of pathogenicity factors (Pinon and Frey 1997). The emergence of new pathogenic races occurs at an accelerating rate and these new races are quickly spreading over Europe. Such an evolution is partly due to the different mechanisms of resistance found in the interspecific hybrids and the pure species (Lefèvre et al. 1998a). The consequences of the disturbance of the co-evolution system on the $P$. nigra native resource are still largely unknown. It has been observed that pathogen populations found on cultivated hybrids and wild $P$. nigra stands are highly differentiated, even when both stands are sampled in the same location at a distance supposed to be small with

\footnotetext{
${ }^{9}$ The term "rehabilitation" might be more appropriate when only partia structural and functional return to a pre-disturbance state is planned (see also de Vries, this issue).
}

respect to spore dispersion (Pinon and Frey 1997): this suggests that $P$. nigra riparian forests can play the role of an active buffer system able to slow down the evolution of rust, but how long will it last?

From these two points, gene flow and pathogen flow, we see that the native gene resource can be affected by the practices in cultivated poplar stands. From another point of view, native riparian poplar populations are closely dependent on the ecological dynamics of the river systems (Braatne et al. 1996). Riparian poplars are strict pioneer species extremely dependent on their environment. When the dynamics of the ecosystem are altered, e.g., when the riverbed is no longer allowed to move laterally, the ecological requirements for seedling establishment and the conditions which allow the new regeneration to reach the adult stage are no longer fulfilled (Barsoum and Hughes 1998, Mahoney and Rood 1998). This has become the common situation in northwestern Europe (Lefèvre et al. 1998b). Conversely, in a self-sustainable dynamic river system, the complex ecosystem is made up of a mosaic of habitats in a highly structured arrangement in which all demographic stages of poplars can develop. Hence, juvenile and adult poplar cohorts provide specific niches for the fauna and flora of the riparian ecosystem (Rotach, report to the European Populus nigra Network, 2000, unpublished). Poplars even give their names to habitats that are considered of important ecological value (e.g., Populion nigrae). In that respect, poplars are also species of global interest for biodiversity.

Finally, we end up with a global chain in which, on one side, poplar genetic resources support poplar cultivation, with an indirect feedback of cultural practices on the evolution of the wild pool and, on the other side, poplar genetic resources depend on ecological processes while providing specific niches for the riparian biodiversity. This leads to the "poplar smile" illustrated in Fig. 1. It is obvious that gene resource management has to deal with genetic management ("breeding" in a broad sense) as well as with ecological management at the same time.

\section{A combined ex situ / in situ strategy is currently implemented on a broad scale}

P. nigra was chosen as one of the pilot Networks for the EUFORGEN program at its beginning in 1994. Six years later, thanks to the efforts of the EUFORGEN coordinator, 23 countries participate in this Network, which gives us a unique opportunity of developing conservation activities at the species range scale (Frison et al. 1995; Turok et al. 1996, 1997, 1998b, 1999; Borelli et al. 2000). The Network has through time developed a combined ex situ and in situ strategy.

Another responsibility of the EUFORGEN Networks is to identify research needs and prepare joint research proposals. The EU-funded research project EUROPOP (FAIR5-PL973386 ), ending in 2001, will tell us how the genetic diversity is distributed among natural populations over the natural range and how the current national gene banks of $P$. nigra collectively represent this natural diversity (van Dam and de Vries, 1999, see also the web page www.alterra.nl/onderzoek/producten/websites/europop/europop.htm). For $P$. nigra, the implementation of ex situ conservation does not raise unexpected questions for research.

\section{The ex situ strategy}

As a first step, the Network emphasized the co-ordination of ex situ activities that several countries had already started 


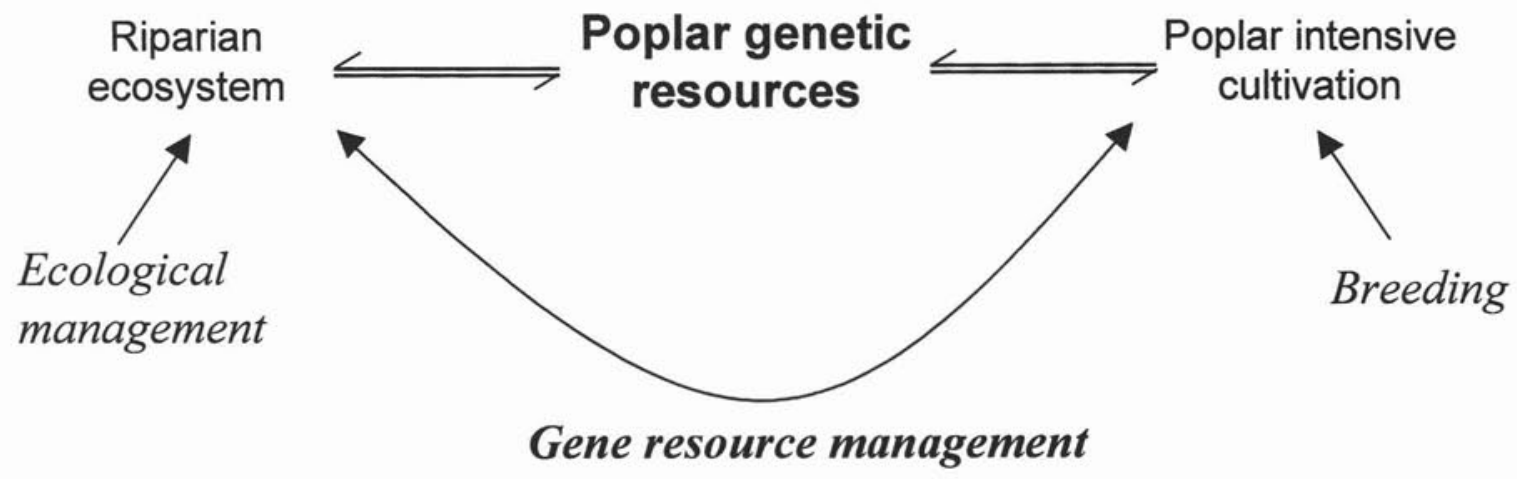

Fig. 1. The central position of poplar gene resource management ("the poplar smile").

$\stackrel{2}{\stackrel{2}{2}}$

ff the frame of their poplar breeding programs. Guidelines for The identification of the pure species, also used to detect Gybrid types in forest stands, guidelines for safe conservation Фี germplasm collections and lists of descriptors were estabPished.

F A common set of reference clones for the evaluation of the different national collections was established: this material was ivxchanged among Network members and it is made available \$o all ${ }^{10}$.

The database of European clone collections was created: it Sow contains 2789 accessions from 19 national collections (Fig. 2). Hifs database is updated annually and should also serve for gimplasm exchange on a worldwide basis. All these outputs ârgavailable on the Internet (see web page: www.ipgri.cgiar.org).

\section{a)}

$\exists$ L Z्रation of genetic resources of forest tree species (PalmbergFireche 1998). This was stated by the EUFORGEN $P$. nigra Network, and the same strategy was recommended for all Popollus species by the International Poplar Commission (SteenackTrs 1996). In situ conservation has already been applied to sevEral forest tree species, either at the national (Teissier du Fros and Bilger 1995) or at the international scale (Koski et al. 7997). However, the implementation of an in situ strategy for pioneer species that needs a complex and dynamic ecosysfis not straightforward: not only forestry practices are congerned, but more generally the ecological management of the whole riparian ecosystem. The EUFORGEN Network will soon \$ublish a technical bulletin for in situ conservation of $P$. nigra (Lefèvre et al. 2001). Such a strategy includes various kinds of in situ conservation activities, from nature reserve areas where black poplar gene resource conservation becomes one of the multiple objectives pursued, to specifically restored populations: these activities are presented in detail in the technical bulletin. Then, possible impacts of management practices on the processes of evolution of black poplar genetic resources are reviewed: river management, forestry practices, other

\footnotetext{
${ }^{10}$ The material used as standard for the evaluation of the national collections includes a set of 15 commercial clones, and a core collection of P. nigra from the whole range of the species. The current core collection contains 39 clones from 18 countries, latitude ranging from $38^{\circ} \mathrm{N}$ to $53^{\circ} \mathrm{N}$, longitude from $00^{\circ} \mathrm{W}$ to $26^{\circ} \mathrm{E}$, altitude from 1 to $1500 \mathrm{~m}$.
}

land uses. General recommendations are also made for the initial establishment of restored populations. Finally, following the procedure that was proposed by Namkoong et al. (1996), three kinds of indicators - ecological, demographic and genetic - are proposed as complementary tools to follow up the in situ activities.

We are reaching the point where general recommendations can be provided. But research is still much needed in various fields to provide figures and determine threshold values: what should be the size of a conservation unit, what are the key processes for the maintenance of species "adaptability," and how much do the current practices influence these processes? In situ conservation units are submitted locally to specific management practices; however, the evolution of poplar diversity also involves processes at the metapopulation level: therefore, we have to cope with the impact of uncontrolled practices outside the conservation unit. Two European research projects in genetics and ecology will contribute to the definition of quantified guidelines (EUROPOP, already mentioned; FLOOBAR2, see www.geog.cam.ac.uk/RESEARCH/flobar2.htm). In addition, further investigation on the interactions between the cultivated and the wild gene pool is also needed. To make the link between results of research and implementation, we face the problem that the scale of management does not necessarily fit the scale of biological processes (see also de Vries, this issue). Much research work has been devoted to the local scale (the stand considered as a population), but there is a need for up-scaling to more complex levels: the riparian forest as a mosaic of ecosystems, the river drainage as the scale of the metapopulation. Especially for pioneer species like poplars, which have a population turnover tightly linked to the ecological dynamics, we need global models of evolution including demographic, genetic and ecological approaches. In addition to these fields, there is also a need for investigation into management itself: multiple objective management and decision making (Kangas and Pukkala 1996, Haight and Travis 1997).

\section{Can Populus nigra serve as a model case for forest gene resource conservation programs?}

The concept of studying a model case is sometimes abusively used to justify a research program regardless of the effective help it can bring to other situations. What should we expect from studying a model case for gene resource conservation? At least we can expect four characteristics: (i) the model is rep- 


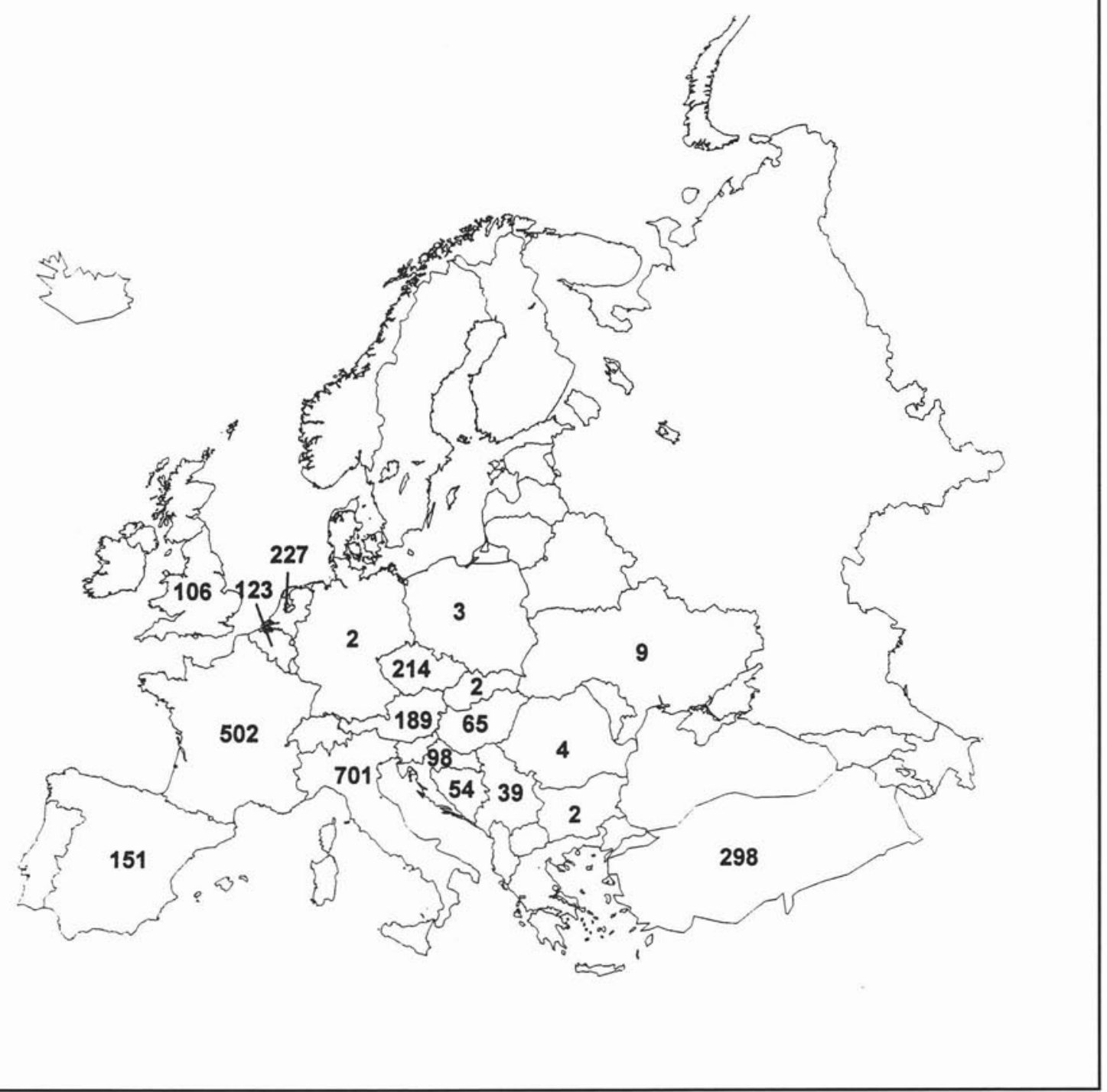

Fig. 2. Origin of the material maintained in the European Populus nigra gene-banks (EUFORGEN database of clone collections).

resentative of various situations of interest, (ii) the model is more easily manipulated and further developed as compared to similar programs, (iii) the model can be evaluated, (iv) various options can be tried experimentally using the model. We will briefly review these four points.

At the species level, it is clear that many riparian poplars in Europe, North America and Asia follow the same "poplar smile" model with both intensive breeding and ecological aspects. In that respect, we can expect that other poplar species and willows (Stott et al. 1985) could also benefit from the experience in $P$. nigra gene resource conservation programs. Moreover, it is noticeable that $P$. nigra has been considered as a case study for gene resource conservation of "wild relatives of cultivated plants," thus extending the scope out of forestry (Arbez and Lefèvre 1993, Heinze 1998). In the case of $P$. euphratica or $P$. alba, other priority Populus species for gene resource conservation, the breeding side of the "poplar smile" is less important, but that could change rapidly. At the ecosystem level, the riparian forests are given priority for three main reasons: they contain an important contribution to biodiversity, they often play the role of a buffer zone between agricultural land and freshwater systems, and their natural dynamic processes have been altered due to human activities. Moreover, as part of their biodiversity, they contain various tree species of interest for gene resource conservation including valuable hardwoods, and the same conservation activities could obviously serve several gene resource conservation programs. We can certainly conclude that black poplar gene resource conservation programs address questions of more general interest.

The effects of ex situ conservation of poplars, which includes dynamic conservation of breeding populations in the frame of a recurrent selection scheme (Bisoffi and Gullberg 1996), have been experienced for decades now. The implementation of the in situ strategy is very recent, but at least in the case of $P$. nigra in Europe, we can say it has started on a broad international scale. Today, scientists from various fields of research meet together and contribute to the elaboration of applied in situ conservation or restoration projects that are launched simultaneously. This allows a direct and reciprocal feedback between research and management. 
Public awareness was given priority by the EUFORGEN Network, probably because of the particular status of the species: talking about poplars, the questions of clonal forestry, interspecific hybridization, exotic germplasm and ecology of riparian sites can be raised. Sustainable management of the resource requires that people with different interests (wood production, gene conservation, ecology, landscaping, navigation, recreation, etc.) can discuss on a common and scientifically sound basis. The dialogue between both sides of the "poplar smile" has certainly been reinforced, in our European countries, through the help of the conservation activities. For all these aspects, the poplar gene resource conservation programs are perhaps ahead when compared to other related situations.

The next characteristic is one of our challenges for the future. The evaluation of ongoing conservation programs requires the development of criteria and indicators: for the first time, this approach has been practically initiated on $P$. nigra, but we are at a starting point. We still have to work on estimating the cost of conservation, which will probably be easier for ex situ than for in situ strategies. But even more difficult will be estimating the cost of no conservation (Weitzman 1993).

Finally, can we afford to study various options for gene resource conservation in forest trees on a real scale? This would surely be needed: experimental work in the laboratory cannot answer all the questions raised by conservation in the forest landscape. We can consider that all conservation projects today are experimental: therefore, much effort should be devoted in the near future to following up the evolution of genetic diversity in these programs. In particular, poplars have a relatively short interval between generations and the time scale of evolution in the riparian ecosystem is also relatively short as compared to climactic forest ecosystems. Therefore, we can expect that interesting information may rapidly come from ongoing poplar conservation programs.

We currently put much effort into building up specific gene resource conservation networks. But this should not be an argument to forget about sustainable gene resource management outside the conservation networks (Savolainen and Kärkkäinen 1992), even for our target species. Furthermore, most species cannot be maintained through a conservation network approach alone. Teaching population biology and genetics in the normal course of forestry and, more generally, public awareness are of major concern for the future of our forests.

\section{References}

Arbez, M. and F. Lefêvre F. 1993. Towards a European forest genetic resource programme: objectives and general conception - A case study concerning the black poplar (Populus nigra L.). In Proc. Workshop Council of Europe "Conservation of the Wild Relatives of European Cultivated Plants: developing integrated strategies," Neuchâtel (Switzerland), 14-17/10/1993. 8 p.

Barsoum, N. and F.M.R. Hughes. 1998. Regeneration response of black poplar to changing river levels. In $\mathrm{H}$. Wheater and C. Kirby (eds.). Hydrology in a changing environment. 1: 397-412.

Benetka, V., J. Mottl, K. Vackova, M. Pospiskova and M. Dubsky. 1999. Estimation of the introgression level in Populus nigra L. populations by means of isozyme gene markers. Silvae Genet. 48: 218-223.

Bisoffi, S. and U. Gullberg. 1996. Poplar breeding and selection strategies. In R.F. Stettler, H.D. Bradshaw, P.E. Heilman and T.M. Hinckley (eds.). Biology of Populus and its implications for management and conservation. pp. 139-158. NRC Res. Press, Ottawa.

Borelli, S., S. de Vries, F. Lefêvre and J. Turok. 2000. Populus nigra
Network. Report of the sixth meeting, 6-8 February 2000, Isle sur la Sorgue, France. International Plant Genetic Resources Institute, Rome, Italie. 55 p.

Braatne, J.H., S.R. Rood and P.E. Heilman. 1996. Life history, ecology, and conservation of riparian cottonwoods in North America. In R.F. Stettler, H.D. Bradshaw, P.E. Heilman and T.M. Hinckley (eds.). Biology of Populus and its implications for management and conservation. pp. 57-85. NRC Res. Press, Ottawa.

European Community. 1992. Directive 92/43/CEE concernant la conservation des habitats naturels ainsi que de la faune et de la flore sauvage. Journal Officiel des Communautés européennes 1992. Numéro 206 du 22/7/9. 7 p.

Frison, E., F. Lefêvre, S. de Vries and J. Turok. 1995. Populus nigra network. Report of the first meeting, 3-5 October 1994, Izmit, Turkey. IPGRI, Rome, Italy. 52 p.

Haight, R.G. and L.E. Travis. 1997. Wildlife conservation planning using stochastic optimization and importance sampling. For. Sci. 43: 129-139.

Heinze, B. 1997. A PCR marker for a Populus deltoides allele and its use in studying introgression with native European Populus nigra. Belg. Journ. Bot. 129: 123-130.

Heinze, B. 1998. Introgression in the poplars (Populus sp.) due to hybrid poplar cultivation. In N. Werker and G.B.A. van Reenen (eds.). VIIth International Symposium "Plant Evolution in Man-made Habitats," 10-15 August 1998, Universiteit van Amsterdam, Niederlande. IOPB Newsletter Special Issue. pp. 83-84.

Kangas, J. and T. Pukkala. 1996. Operationalization of biological diversity as a decision objective in tactical forest planning. Can. J. For. Res. 26: 103-111.

Koski, V., T. Skroppa, L. Paule, H. Wolf and J. Turok. 1997. Technical guidelines for genetic conservation of Norway spruce (Picea abies (L.) Karst.). pp. 5-12. International Plant Genetic Resources Institute, Rome, Italy.

Lefêvre, F., M.C. Goué-Mourier, P. Faivre-Rampant and M. Villar. 1998a. A single gene cluster controls incompatibility and partial resistance to various Melampsora larici-populina races in hybrid poplars. Phytopathology 88: 156-163.

Lefèvre, F., A. Legionnet, S. de Vries and J. Turok. 1998b. Strategies for the conservation of a pioneer tree species, Populus nigra L., in Europe. Genet. Sel. Evol. 30(suppl.1): 181-196.

Lefèvre, F., N. Barsoum, B. Heinze, D. Kajba, P. Rotach, S. de Vries and J. Turok. 2001. Technical Bulletin on in situ Conservation of Populus nigra. International Plant Genetic Resources Institute, Rome, Italy (in press).

Mahoney, J.M. and S.B. Rood. 1998. Streamflow requirements for cottonwood seedling recruitment - an integrative model. Wetlands 18: 634-645.

Namkoong, G. 1997. A gene conservation plan for loblolly pine. Can. J. For. Res. 27: 433-437.

Namkoong, G., T. Boyle, H.R. Gregorius, H. Joly, O. Savolainen, W. Ratnam and A. Young. 1996. Testing criteria and indicators for assessing the sustainability of forest management: genetic criteria and indicators. CIFOR Working Paper \#10. 12 p.

Palmberg-Lerche, C. 1998. Management of forest genetic resources: some thoughts on options and opportunities. pp. 43-44. Forest Genetic Resources No 26. FAO, Rome, Italy.

Pinon, J. and P. Frey. 1997. Structure of Melampsora larici-populina populations on wild and cultivated poplar. Eur. J. Plant Pathol. 103: 159-173.

Savolainen, O. and K. Kärkkäinen. 1992. Effect of forest management on gene pool. New Forests 6: 329-345.

Steenackers, V. 1996. Towards a global management of poplar genetic resources. Proc. XIXth Session of the International Poplar Commission (FAO), Budapest, Hungary. 13 p.

Stott, K.G., V. Steenackers and S.M.G. de Vries. 1985. To conserve and improve the genetic resources of Salix within NorthWestern Europe. In M. Ridé and V. Steenackers (eds.). Wood as a 
renewable raw material. pp. 109-112. Workshop CEC R\&D Programme, Geraardsbergen, Belgium.

Teissier du Cros, E. and I. Bilger. 1995. Conservation of beech genetic resources in France. In Genetics and Sylviculture of Beech. pp. 196-209. Proc. IUFRO Project Group P1.10-00, Mogenstrup Denmark.

Turok, J., F. Lefèvre, L. Cagelli and S. de Vries. 1996. Populus nigra Network. Report of the second meeting, 10-12 September 1995, Casale Monferrato, Italy. IPGRI, Rome, Italy. 27 p.

Turok, J., F. Lefềre, S. de Vries and B. Toth. 1997. Populus nigra Network. Report of the third meeting, 5-7 October 1996, Sarvar, Hungary. IPGRI, Rome, Italy. 77 p.

Turok, J., F. Lefèvre, S. de Vries, N. Alba, B. Heinze and J. Van Slycken. 1998. Populus nigra Network. Report of the fourth meeting, 3-5 October 1997, Geraardsbergen, Belgium. IPGRI, Rome, Italy. $85 \mathrm{p}$.
Turok, J., F. Lefèvre, S. de Vries, B. Heinze, R. Volosyanchuk and E. Lipman. 1999. Populus nigra Network. Report of the fifth meeting, 5-8 May 1999, Kyiv, Ukraine. International Plant Genetic Resources Institute, Rome, Italy. 88 p.

Turok, J., C. Palmberg-Lerche, T. Skroppa and A.S. Ouédraogo. 1998a. Conservation of Forest Genetic Resources in Europe. In Proceedings of the European Forest Genetic Resources Workshop, 21 Nov. 1995, Sopron, Hungary. IPGRI, Rome. 60 p.

van Dam, B.C. and S.M.G. de Vries. 1999. European cooperation in research on Black Poplar. IPGRI Newsletter for Europe 15: 7. Varela, M.C. and G. Eriksson. 1995. Multipurpose gene conservation in Quercus suber - a Portuguese example. Silvae Genet. 44: 28-37.

Weitzman, M.L. 1993. What to preserve ? An application of diversity theory to crane conservation. The Quarterly Journal of Economics Feb 1993: 157-183. 